Teosofia: Indonesian Journal of Islamic Mysticism, Vol. 8, No. 2, 2019, pp. 117-130

e-ISSN: 2540-8186; p-ISSN: 2302-8017

DOI:

\title{
CHINESE PESANTRENAND CHINA'S ACCEPTANCE TO ISLAM A study on Counseling Spirit in Chinese Pesantren Hu Dengzhou Jingtang Jiaoyu
}

\author{
Moh. Khoerul Anwar, Nur Musyafak, Zaen Musyrifin \\ Central China Normal University \\ State Islamic University Sunan Kalijaga \\ moh.anwar@mails.ccnu.edu.cn, \\ nurmusyafak29@gmail.com, zaenmusyrifin90@gmail.com
}

\begin{abstract}
:
Counseling is a psychological service provided by people who have the skills to listen well, the skills to understand others, and the skills to humanize people. These three skills are owned by one Islamic figure who teaches about Islamic culture in China to establish a pesantren (Jingtang Jiaoyu in Chinese) that has now increased. $\mathrm{Hu}$ Dengzhou is the early figure of Islamic education in China, and some concept developed by him is part of counseling spirit. The idea applied is a) psychological services are given classically for people who need peace and peacefulness b) service processes are given gradually according to the assessment, if viewed from the aspect of counseling with the services provided in accordance with the results of the need assessment, c) individual counseling are served for each student, as the teacher (kyai in Indonesia) that accompanies each student (santri in Indonesia) so as to understand the characters, behaviors, personalities, and skills of students. The conclusion of this article is that the spirit of counseling in China has existed since ancient times and has applied in pesantren based on Islamic culture and give big impact in interreligious peace in China. Then Islam in China is not problematic because the Chinese government also recognizes that Islam is part of a culture that has existed since ancient times.
\end{abstract}

Keywords: Spirit Counseling, Chinese Pesantren, Hu Dengzhou.

\section{A. Introduction}

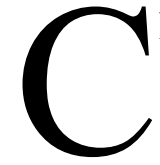

hina has conducted counseling or therapy since 2500 years ago and demonstrated by the practice of treatment using various methods to train emotions and overcome behavioral problems. ${ }^{1}$ It shows that China has been aware of the importance of cultivating emotions in addressing life issues. However,

1 Higgins, L. T., Davey, G., Gao, X., Ni, Z., Lang, L., \& Zheng, R. (2008). Counselling in China: Past, present and future. Psychology and Developing Societies, 20(1), 99-109. https://doi.org/10.1177/097133360702000105. 
there are no policies that govern systematically on counseling and therapy. Thus around the 1980s, the western concept of new counseling psychology was introduced ${ }^{2}$ and then in the year 1985 Professional associations for established counseling, known as the Chinese Association for Mental Health. ${ }^{3}$ That indicates that counseling in China seems much needed because China is one of the largest populations in the world, which is about 1.3 billion. In other words, the level of density and modernization of society makes a variety of problems, whether mental problems, stress, divorce, unemployment, depression or other issues. It is, in line with the Western world, when the emergence of various issues such as increasing divorce rates, unemployment and psychological problems such as eating disorders, now brings increased levels of unhappiness to China. ${ }^{4}$ The problems experienced and public awareness makes the level of counseling profession more needed.

Counseling as an independent scientific discipline and emerging method is relatively new in China. Nevertheless, the country has a long history of psychological thinking. It is in line with the Philosophers of ancient China and traditional medicine. ${ }^{5}$ They were the philosophers of Confucianism, Taoism, and Buddhism. For thousands of years, this philosophy provides a basis for supporting individuals with emotional problems and providing the underlying theoretical for Traditional Chinese medicine, which the only aid to psychological problems beyond That provided by close social networks such as family and friends. ${ }^{6}$ On this basis also, the author tries to discuss how the spirit of counseling in pesantren in China because one of the Confucian philosophical disciples learned Islam and established pesantren in China, namely $\mathrm{Hu}$ Dhengzhou.

The concept adopted by $\mathrm{Hu}$ Dhengzhou is the concept of Confucianism combined with Islamic concepts. The two concepts are well integrated without having contradiction to the rules and policies of the government; it is also in line with the concept of pesantren. The concept of pesantren prioritizes peace and convenience for those who will learn or study. In line with this, without being intercepted, it is part of a counseling service that emphasizes the convenience of counselled or clients in

2 Higgin and Zheng. (2002). An introduction to Chinese psychology: Its historical roots until the present day. The Journal of Psychology, 136(2), 225-239 see too in JING, Q.C. (1994). Development of psychology in China. International Journal of Psychology, 29(6), 667-675.

3 A Brief Introduction to China Association for Mental Health, n.d.

4 Davey and Higgin. (2005). Fear in China. China Review, 33, 30-33. See too in Khan, A.R., \& Riskin, C. (2001). Inequality and poverty in China in the age of globalization. Oxford: Oxford University Press. And look at Sh EN, X. (1997). Saving children (in Chinese). Psychology World, 1, 16-17.

5 Higgins, L. T., Davey, G., Gao, X., Ni, Z., Lang, L., \& Zheng, R. (2008). Counselling in China: Past, present and future. Psychology and Developing Societies, 20(1), 99-109. https://doi.org/10.1177/097133360702000105

$6 \quad$ Ibid. 
helping to solve the problem process of service given in a classical, group, and individual method. The classical service is provided to all the people who come, while the group service is adapted to the needs of its members while the individual services are focused on who already has expertise. In other words, the main concept in the educational process of China's trends puts forward the needs of society. The term in counseling that is adjusted to the need of assessment is found. Therefore, the authors feel the need to dig deeper into how the spirit process of counseling based on Chinese pesantren is performed by one of the disciples of Confucianism so that nowadays can grow rapidly.

\section{B. Spirit Counseling in Chinese Pesantren}

Before discussing the spirit of counseling in Chinese pesantren, first, we need to understand about the situation of Muslims in China. Some media inform that there is a different treat to Muslims there. But the treat is an action toward off radical understands. So it is not surprising that the war policy against terrorism in China makes the two areas treated differently. For example, Tirto.id ${ }^{7}$ reports that a bad situation occurred due to the emergence of separatist movements such as the East Turkestan Islamic Movement (ETIM), which has existed since the 1990th. Beijing categorizes ETIM as a terrorist group affiliated with Al-Qaeda, so it deserves to be fought. But the contrast treatment between Muslims Hui and Uighur showed how Beijing distinguishes Muslims into two groups, namely good Muslims and bad Muslims. The Chinese government's openness to Muslims Hui could not be removed from the assimilation factor between Islamic and Chinese tradition. The result of the assimilation could be seen when they adapted Islamic practices with Confucianism. For example: building mosques with a blend of traditional Chinese styles and Islamic styles.

Chinese government's hospitality indicator towards Hui, citing articles The Economist titled "The Hui: China's other Muslims" (2016), ${ }^{8}$ Can be seen from the number of mosques in Ningxia (where Hui's origin) has doubled since 1958, from 1,900 to 4,000. Besides, concerning the Muslim situation in China, vice president of the Islamic Association of China, Abdul Amin Jin Rubin said that in Xinjiang, there was a terrorist eradication activity and other violent activities, but it was not specifically targeting the group Certain ethnic or religious. Even purely, vocational education and training facilities do not directly target a participatory group. So far, the program has

7 See in https://tirto.id/muslim-hui-dan-uighur-mengapa-diperlakukan-berbeda-di-cina-dcFR, diakses pada 27 Oktober 2019.

8 See in https://www.economist.com/china/2016/10/06/chinas-other-muslims, diakses pada 27 Oktober 2019.

Teosofia: Indonesian Journal of Islamic Mysticism, Vol. 8, No. 2, 2019 
been effectively stabilizing conditions in Xinjiang. ${ }^{9}$ Based on the exposure, it is understood that the Chinese government is essentially very open to Muslims, especially those who want to pursue their education in China. Issues related to the different treatment of Muslims there relate to the Chinese government in combating terrorism and other radical understanding.

With regards to the world of education in China, the challenges and difficulties of counseling in the Chinese colleges have been examined by Ya Zhang, Wensheng Yang, Mingbo Liu, and Mengyang Wua (2016) ${ }^{10}$ Explaining the sharing of personal observations about central issues in mental health at the Chinese College. Compared to previous generations, students in China are currently struggling with emotional health issues and behaviors. Meanwhile, psychological counseling in China is already on the fast track to answer the challenges and opportunities in providing professional services to its students. The way it is by exploring the adoption of Western theories on mental health care. Observation results are expected to get more responses and support from colleagues around the world about multicultural counseling. From the observation and analysis conducted by Ya Zhang et al, the author understands that counseling in the existing universities in China has been developed to answer problems of multicultural life in China.

As explained by Lim, Lim, Michael, Cai, \& Schock (2010) ${ }^{11}$, The development of college counseling comes with many shortcomings and problems. Though the discussion of psychology and human beings has a history in China, western psychological counseling approaches have also been proven to be implemented in eastern contexts. However, both Chinese and non-Chinese who provide mental health services and training in China need to be considered sociocultural contexts. According to the authors, the explanation strengthened the existence of counseling services related to sociocultural in some universities in China but still many shortcomings. Most students who follow counseling get positive effects and have the hope of continuing to support the counseling process. Many college counseling centers in Shanghai and Wuhan (other central cities in HuBei province) set an 8-10 session limit for free face-to-face counseling to meet the demands of counseling services. Many countries support the idea that these counseling session limits need to be applied. However, if the student needs long-term support, then the counselor must extend the counseling session.

9 See in https://www.liputan6.com/global/read/3898416/ulama-asosiasi-islam-china-pemberitaanbarat-soal-muslim-uighur-di-xinjiang-berlebihan, diakses pada 27 Oktober 2019.

10 Ya Zhang, Wensheng Yang, Mingbo Liu, and Mengyang Wua, "Challenges and Difficulties About College Counseling in China: Response to Portnoy (2013), Journal of College Student Psychotherapy, Routledge Taylor\&Fancis Group, Vol. 30, No. 1, 64, 2016.

11 Lim, S.-L., Lim, B. K. H., Michael, R., Cai, R., \& Schock, C. K. (2010). The trajectory of counseling in China: Past, present, and future trends. Journal of Counseling \& Development, 88,4-8. 
Furthermore, the counseling services applied are aimed at addressing the general development of students, such as confidence, social interactions, emotional management, new student self-adjustments, and family influences. Students can take advantage of sharing the problems they have and learn from group counseling. Group Counseling has partially alleviated the limited human resources problem. From the results of the analysis, the author understands that some students are eager to attend counseling services. This is characterized by the presence of several requests to add a counseling session.

Speaking of counseling in Chinese pesantren indeed not separated from the existence of mosque pesantren that nuance of Chinese culture. Some of them in Bogor there is Pesantren At-Taibin or more popularly known as Pesantren Chinese Klanteng Building, which was founded by a Mu'allaf Teonghoa and is a former criminal. Sri Lestari, ${ }^{12}$ presented a mixture of Chinese and Javanese culture in Lasem, Rembang, Central Java not only stop on a piece of writing batik, in the daily life in the areas of tolerance values between ethnic and religious is very strong in the city dubbed "small Chinese " or " The old Beijing city is small", and mentions as " City of Santri".

Related to China and Pesantren, Lilis dan Agung, ${ }^{13}$ reported ambassadors of the People's Republic of China, Xie Feng had visited Pesantren Kyai Haji Aqiel Siroj (KHAS) Kempek di Desa Kempek, Kecamatan Gempol, Kabupaten Cirebon. On that occasion, Xie Feng encouraged the exchange of students. Xie Feng proposed that the Chinese government protect the rights of Muslims to perform acts of worship and provide preferential facilities and policies to Muslim students to help them learn Islamic sciences. From this explanation, the author understands that counseling services need to be done in the Pesantren that is in China because Pesantren is part of the facility for Muslim students in China. Counseling services need to be done to help solve the problems that are owned by Muslim students in China.

\section{The Development of Hu Dhengzhou Jingtang Jiaoyu}

Associated with one disciple of Confucianism who had considerable influence in the world of Islamic Education, namely Hu Dhengzhou now the role of education (Pesantren) China in the past, present, and future.

12 Sri Lestari, "Toleransi Antar Etnis di "Kota Cina Kecil" Lasem", dalam https://www.bbc.com/indonesia/berita_indonesia/2015/02/150219 lasem_toleransi, diakses pad 30 Oktober 2019.

13 Lilis Handani dan Agung Sasongko, "Dubes Cina Dorong Pertukaran Santri”, dalam https://www.republika.co.id/berita/dunia-islam/islam-nusantara/17/03/15/omumgf313-dubes-cinadorong-pertukaran-santri, diakses pad 30 Oktober 2019.

Teosofia: Indonesian Journal of Islamic Mysticism, Vol. 8, No. 2, 2019 


\section{Jingtang Jiaoyu in the Past}

Pesantren does not only exists in Indonesia. In China, in which the majority of the Community has no belief or atheist, there is also an Islamic educational institution that has the same role as the Pesantren as an educational platform to form the people who Good behavior. Since the time of Rasulullah spreading Islam as a religion of Rahmatan Lil Alamin on the face of the earth, China, as one of the countries that have a long enough history, has a great influence on the development of Islam. Because the time and way of spreading Islam in China are different so that the model and the process of forming education institutions are not the same as those already in Arab.

The beginning of Islamic educational institutions in China appears in the area of Xinjiang and around, but only limited non-formal institutions that teach students the sciences of Tauhid, Qur'an, and Hadith. During the Tang dynasty (618-907) Many Arabs went to China to trade and spread the Islamic religion, because the time of their stay in China was long enough, so it is not uncommon that began to settle in the area until some were married and had children Wedding results with local people. Islamic education, or in Mandarin, referred to as "Jingtang Jiaoyu" starting from the education called "Fanxue" in the Tang Dynasty, although education at the time was less than perfect, it was a good start to begin Islamic education in China.

"Fanxue" Education has two types of institutions, namely state and private institutions. ${ }^{14}$ Institutions that are managed directly by the Government have the purpose of printing the experts of translators, diplomacy, and so on. But for private educational institutions is more focused on learning the basic Islamic religion. Because the educational institutions "Fanxue" increasingly long growing, both are managed by the Government, as well as by the private. Then from here also developed a high school that teaches about Islam.

Furthermore, after going through the development of three dynasties, Islamic educational institutions also underwent many changes. One of them is the Islamic institution that makes Mandarin as a language of everyday communication in teaching and learning activities, most of the students who are in this institution are Chinese themselves as well as foreigners who have chosen to settle in Local area and has been able to melt into local communities. Another, the institution that has pupils with a different language of communication, so that the educational institution is not able to fulfill the demand of each student, eventually unable to survive.

Islamic educational institutions in Xinjiang were able to expand faster than the institutions in mainland China, because, in 915M, a king in Xinjiang strongly supported the development of Islam there, so as to accelerate the development of Islam, he An example of Islamic educational institutions in the Middle East,

14 丁土仁. 《中国伊斯兰教经堂教育》.甘肃人民出版社, 2011 
established a sizable Islamic educational institution, having professional educators, as well as very complete subjects. It is one of the largest Islamic educational institutions of the time in Asia. ${ }^{15}$ The Islamic educational institution also became the first official institution to appear in Xinjiang, then this kind of education was called Jingtang Jiaoyu. Not long afterward, many other educational institutions have come to appear like a walk with the rapid development of Islam there. There are at least ten more Islamic educational institutions in Xinjiang that became early in the development of Islamic education and culture. ${ }^{16}$

When the Islamic educational institutions in Xinjiang began to flourish, mainland China still began to build an official college of Islam and able to meet the needs of the pupils. So that educators in mainland China feel the need for a collegebased Islamic institution in the Ming dynasty, then they begin to study the development and management of the Islamic College of Islamic Institutions in Xinjiang is quite mature. During the Ming Dynasty $(1386$ - 1664M), the Islamic educational institution changed again. There are Islamic universities in China, which are devoted to the study of Islam, such as the Quran and Hadith. Being in Xinjiang itself is not the same; Islamic education and culture became a college institution by combining other general lessons in it. Since then, Islamic educational institutions in mainland China have begun to develop into an official college institution. Since the Chinese at the time experienced several changes in the dynasties, of which each dynasty had different policies, such circumstances resulted in the Islamic educational institutions there experiencing a bullish period perceived by the local Muslim community.

\section{Jingtang Jiaoyu in Hu Dengzhou era}

Based on the history of Islamic development in China, in the centuries before 18M Islamic educational institutions, "Jingtang Jiaoyu" from the concept of teaching and more important subjects gained more influence from the Middle East countries, especially the Arabs are many Trade with the Chinese. Later in the 18th century, the concept of education was more inclined to the concept of Indian education and used the same subjects that had been used in India, such as poetry collection, literature, Fable Story, Tatakrama, education norms Community and so on. These subjects were

15 余振贵. 《中国历代政权与伊斯兰教》.宁夏人民出版社, 1996

16 任红. 《维吾尔族伊斯兰教经堂教育的历史及其影响》.中国穆斯林 2009年第5期

Teosofia: Indonesian Journal of Islamic Mysticism, Vol. 8, No. 2, 2019 
already in use in the centuries before $16 \mathrm{M}^{17}$, even until now colleges in India and Pakistan are still applying similar subjects 18.

As already described above, since the Tang dynasty has emerged Islamic educational institutions in China, although from the concept of teaching, subjects, and teachers still not good, this is quite good as the beginning of the development of Islamic education. It was difficult to conclude who was the first founder of the Islamic Educational institution "Jingtang Jiaoyu," but it was a lot of historical data explaining that $\mathrm{Hu}$ Dengzhou was the first founder of the educational institution "Jingtang Jiaoyu".19

Hu Dengzhou, as a person who has a major influence in the development of the Islamic Educational institution "Jingtang Jiaoyu" Until now, it is good to explain the figure of Hu Dengzhou. Hu Dengzhou (1522-1597) has another name of Muhammad Abdullah Ilyas, known not only as an Islamic scientist in China, but he is also a figure of Islamic education. He is known as the man who had a pivotal role in developing the Islamic educational institution "Jingtang Jiaoyu". This educational institution itself is a traditional Islamic education system in China, which generally conducts learning activities about the religious sciences and the Qur'an in the mosque, so it is also called the education in the mosque (Siyuan Jiaoyu). This kind of education has been there for a long time; one example is where Hu Dengzhou studied Islamic law and the Qur'an in his childhood (where he studied the teacher Gao). The teachers who are educators at the site are the ones who have a broad knowledge of Islam. This kind of education has influenced the influence of Southeast Asia and Xinjing to use this educational pattern first.

$\mathrm{Hu}$ Dengzhou was born in a wealthy family in the province of Shaanxi, Xianyang City. Since childhood, Hu Dengzhou is known as a smart person and has a remarkable spirit of learning; the principle in life makes himself a humble man and has a strong stance. He has since started to study Confucianism (Ruxue), and he also studied the Koran to the great teacher (Gao teacher) near where he lived. He was a man of science, never to be content in search of science. In some historical records explained, $\mathrm{Hu}$ Dengzhou had studied religious sciences to various regions, and there were four of his most famous teachers and became a record of Islamic history in China. The first is the Great teacher Gao (Gao Taishi), Gao's teacher is a Muslim in China who has extensive knowledge. Hu Dengzhou shouldn't have learned the science of religion and Quran to Gao teacher since childhood. His second teacher, national

17 Maria Eva Subtelny, The Curriculum of Islamic Higher Learning in Timurid Iran in The Light of Sunni Revival Under Shah-Rukh, in Journal of the American Oriantal Society. Vol 115. No 2 (AprJun, 1995)

18 Prof M. Hamiddin Khan, History of Muslim Education. Karachi: Qureish Art Press, 1967

19 周狺藩主编. 《清真大典》.黄山书社，2005，第二十册 
cultural Teacher (Guoxue Mingshimou), in addition to studying Islamic sciences, Hu Dengzhou also realized the importance of learning Confucianism (Ruxue) to train himself as a person who understands the role of culture and moral. It was told that $\mathrm{Hu}$ Dengzhou had met with the Prophet Hidir, and had learned to him. Hu Dengzhou, as a Muslim, can meet with the Prophet Hidir is a privilege, so he is also known among the Sufi people.

Besides, Hu Dengzhou studied to a Muslim from Arabia. He met his teacher on the trip when he would go to trade. He told that he wanted a book that the Muslim Arab had, but he did not give the book that $\mathrm{Hu}$ Dengzhou wanted until he finally went on his way to trade, and then found the book he area and buy it immediately. However, he was unable to understand all the contents of the book he had bought. Hu Dengzhou decided to find the Arabs to study the book. It was unexpected, in the period that soon $\mathrm{Hu}$ Dengzhou then reunites with the Arabs, and began to go to him. After learning many sciences from various regions and some teachers are knowledgeable, then as what has been taught in Islam and Confucianism to practice the science that has been studied, Hu Dengzhou decided to open the school His own home (Shaanxi province), without charging for his students. This kind of education Model was first implemented by Confucius (551-479 BCE) in spreading his teachings. From the form of instruction applied by $\mathrm{Hu}$ Dengzhou, he tried to incorporate Islamic teachings with Confucianism so that the wider community could accept his teaching, hence become Islamic Confucius (Hui er jian ru), merging of religious teachings Islam with local cultural teachings that have been ingrained and more acceptable to local people. If you look at the development of Islam in Indonesia, such a thing is not much different from the "Islam (in) Nusantara" The Tawasuth, Tawazun, and Tasamuh.

$\mathrm{Hu}$ Dengzhou at the beginning of opening a private school in his home, he taught the Arabic language and Islamic teachings, educating many students from different regions was a tough challenge for him. The Model of education used by $\mathrm{Hu}$ Dengzhou was to combine and integrate Chinese culture with Islamic culture to be more easily accepted by Chinese people in general. As many students come to study religious knowledge, the house that serves as a place to learn to teach is no longer crowded, so it is transferred to mosques that already exist as a center for Islamic Science Education. Until now, the education in this mosque is known as "Jingtang Jiaoyu". It can also be said that Jingtang Jiaoyu's educational culture is an integral part of Chinese Islamic culture.

Furthermore, because of the number of students who came to study, and the teachers in the mosque were less crowded to teach a lot of students so that there were several teachers to serve to teach and educating in the mosque. Most of the teaching councils are experts in certain disciplines. Lectures begin in the morning, in the afternoon used for discussions, and evenings are used for self-study. Since the students

Teosofia: Indonesian Journal of Islamic Mysticism, Vol. 8, No. 2, 2019 
who come in demand not only come from cities in Shaanxi province, many also come from outside the province, then they choose to settle in the neighborhood. For the daily needs of students who are from outside the region assisted by Muslim families around the mosque.

The contribution of a Hu Dengzhou more precisely in developing Jingtang Jiaoyu became a traditional Islamic education in China with a distinctive characteristic that is prominent. One of them makes a good language system and translation rules20. He removed the pre-existing teaching patterns and changed the introductory language to teaching the Mandarin language easily understood by all students who came to gain knowledge. Because since childhood, he has studied the good Chinese language, so it often does Chinese language research and translation method, thus formed a good language system in learning and translation method. Because there is no such thing as the Arabic-Mandarin dictionary, and there is no reference to be made interpreting the intent of the books learned.

Not only in the field of the learning system but Hu Dengzhou also very wellmade in teaching Islam Suni, who had a priest Hanafi. Because previously, most Muslims in some of China embraced Shi'a traditions. In his teaching, Hu Dengzhou guided to the books of Hanafiyah, so that the disciples also used the same teachings and this became the qibla of teaching in most of China, some mosques in Shaanxi province (one of the mosques in the city of Xi'an). The development of Jingtang Jiaoyu's educational concept. Until finally, the methods and content taught by him spread all over China. Therefore, Hu Dengzhou is often referred to as the founder of Jingtang Jiaoyu; this is because of his services and contributions to the development of Islamic education in China are very large and can be felt today.

\section{Jingtang Jiaoyu Now and Future}

The influence of Hu Dengzhou as a man who developed a "Jingtang Jiaoyu" educational institution can still be felt today. Although there are not many mosques that still carry out the activities of learning teaching Quran and hadiths, there are still some who still teach the science of religion, more so when at the semester breaks children begin to flock to the mosque to study. A study in Ningxia, one of the provinces with the majority of the population is Muslims showed that there are about 100 more mosques used to teach the learning process.21 The communities that live there have begun to pay attention to the level of education, so they are not only learning about religious knowledge but also studying other general sciences. This is due to compulsory regulation of learning nine years in China that led them to the

$\begin{array}{ll}20 & \text { 丁士仁. 《中国伊斯兰教经堂教育》.甘肃人民出版社, } 2011 \\ 21 & \text { 马燕. 《宁夏经堂教育现状及发展对策》.中国穆斯林, } 2017\end{array}$ 
youths there to settle this obligation so that they are at least after graduating junior high school can study the science of religion in the mosque.

Not only that, but their awareness in learning Mandarin also began to increase, because of the need for societal with the wider community, so that the Mandarin language becomes a very important language to learn. Also, learning Arabic is one of the languages that must be learned because of their need to understand the Qur'an and other references that speak Arabic, also their need to be a translator to improve Chinese relations With Middle Eastern countries. It is not less important to learn about local cultures to be one of the subjects that must be learned. Not only learn the theory, but this subject is also usually practiced every Friday after the Friday (jumatan) prayer finishes, most of which are practiced directly not far from the fiqh lesson of the day.

The feature of the Islamic educational institution "Jingtang Jiaoyu" which continues to exist until now, combines the tradition of Islamic and Chinese culture so that it can melt into Islam that can be accepted in the wider community. So that no close possibility of the education institution "Jingtang Jiaoyu" will continue to exist along with the development of the time, one such example is the establishment of "Hui Culture Park" with the government support. It is not easy to develop an Islamic educational institution in the country that the majority of non-Muslim people, even agnostics people. There are a few things that need to be considered to continue to develop institutions. One of them enhances basic morals in the social environment. This is in line with Confucian views, as the thinkers remain in place in China, who have the purpose of educating others to become useful humans.

The concept of teaching in the institution itself, such as the subjects that were learned and the teaching book used, should also be considered. As agency managers must continue to improve the quality of the teaching books used, teaching books about Islamic sciences, and general knowledge books, and continually improving courses and curriculum. After the course is repaired, which is not less important is improving the quality of teachers. Furthermore, the latter is determining the direction of the education destination of the mosques, adapting to the hidden and government regulations, to then be a good mosque priest. After becoming a permanent priest in the mosque, at least there are discussions or other similar activities so that the mosque priests can learn from each other and exchange information. If the educational institution "Jingtang Jiaoyu" can innovate and adapt the concept of education with the times, then Islamic educational institutions in China will continue to exist.

\section{Conclusion}

Pesantren in China in the past, present, and future have a relationship that is connected each other. It is as seen, despite the change in dynastic or governmental policy, pesantren in China still has a role in providing education services to the 
community, both Chinese and outside China. The combination of Pesantren with counseling into an integral part, the services given are provided to the needs of individuals and communities both from classical services, groups, and individuals. Therefore, it needs to be maintained and improved so that the community feels comfortable and facilitated for more passionate learning and able to help overcome the problems experienced. The problems that arise increasingly are various, both from social problems, unemployment, divorce, suicide, and other problems. The spirit of counseling combined in the Pesantren is part of $d a^{\prime} w a h$ and helps to handle the psychological state of the Islamic culture-based society. It is also to show that China is a tolerant country for religious believers who are welcome and provided a place of its own with the record of not carrying out religious activities in public in general. Thus, Islam in China is not problematic because the Chinese government also recognizes that Islam is part of a culture that has existed since ancient times. 


\section{Bibliography}

A Brief Introduction to China Association for Mental Health, n.d.

Author. (2019). See in https://tirto.id/muslim-hui-dan-uighur-mengapa-diperlakukanberbeda-di-cina-dcFR, accessed on 27 Oktober 2019

Author. (2019).See in https://www.economist.com/china/2016/10/06/chinas-othermuslims, accessed on 27 Oktober 2019

Author. (2019).See in https://www.liputan6.com/global/read/3898416/ulama-asosiasiislam-china-pemberitaan-barat-soal-muslim-uighur-di-xinjiang-berlebihan, accessed on 27 Oktober 2019.

Davey and Higgin. (2005). Fear in China. China Review, 33, 30-33. See too in Khan, A.R., \& Riskin, C. (2001). Inequality and poverty in China in the age of globalization. Oxford: Oxford University Press. And look at Sh EN, X. (1997). Saving children (in Chinese). Psychology World, 1, 16-17.

Higgins, L. T., Davey, G., Gao, X., Ni, Z., Lang, L., \& Zheng, R. (2008). Counselling in China: Past, present, and future. Psychology and Developing Societies, 20(1), 99-109. https://doi.org/10.1177/097133360702000105

Higgin and Zheng. (2002). An introduction to Chinese psychology: Its historical roots until the present day. The Journal of Psychology, 136(2), 225-239 see too in JING, Q.C. (1994). Development of psychology in China. International Journal of Psychology, 29(6), 667-675.

Lilis Handani dan Agung Sasongko, "Dubes Cina Dorong Pertukaran Santri", dalam https://www.republika.co.id/berita/dunia-islam/islam-

nusantara/17/03/15/omumgf313-dubes-cina-dorong-pertukaran-santri, accessed on 30 Oktober 2019.

Lim, S.-L., Lim, B. K. H., Michael, R., Cai, R., \& Schock, C. K. (2010). The trajectory of counseling in China: Past, present, and future trends. Journal of Counseling \& Development, 88, 4-8.

Maria Eva Subtelny, The Curriculum of Islamic Higher Learning in Timurid Iran in The Light of Sunni Revival Under Shah-Rukh, in Journal of the American Oriantal Society. Vol 115. No 2 (Apr-Jun, 1995)

M. Hamiddin Khan, History of Muslim Education. Karachi: Qureish Art Press, 1967

Teosofia: Indonesian Journal of Islamic Mysticism, Vol. 8, No. 2, 2019 
Sri Lestari, "Toleransi Antar Etnis di "Kota Cina Kecil" Lasem," dalam https://www.bbc.com/indonesia/berita indonesia/2015/02/150219 lasem tolera $\underline{\text { nsi, }}$ accessed on 30 Oktober 2019.

Ya Zhang, Wensheng Yang, Mingbo Liu, and Mengyang Wua, "Challenges and Difficulties About College Counseling in China: Response to Portnoy (2013), Journal of College Student Psychotherapy, Routledge Taylor\&Fancis Group, Vol. 30, No. 1, 66, 2016.

丁土仁.《中国伊斯兰教经堂教育》.甘肃人民出版社, 2011

余振贵. 《中国历代政权与伊斯兰教》.宁夏人民出版社, 1996

任红. 《维吾尔族伊斯兰教经堂教育的历史及其影响》. 中国穆斯林 2009 年第5 期

周狺藩主编. 《清真大典》.黄山书社，2005，第二十册

丁士仁.《中国伊斯兰教经堂教育》.甘肃人民出版社, 2011

马燕. 《宁夏经堂教育现状及发展对策》.中国穆斯林, 2017

马燕. 《宁夏经堂教育现状及发展对策》.中国穆斯林, 2017 